Article

\title{
Sustainability Improvement in the Design of Lightweight Roofs: A New Prototype of Hybrid Steel and Wood Purlins
}

\author{
Harkaitz García ${ }^{1}$, Mikel Zubizarreta ${ }^{2, *}{ }^{\mathbb{C}}$, Jesús Cuadrado ${ }^{1}\left(\mathbb{D}\right.$ and Juan Luis Osa ${ }^{1}(\mathbb{D}$ \\ 1 Department of Mechanical Engineering, University of the Basque Country (UPV/EHU), 48940 Leioa \\ Vizcaya, Spain; harkaitzgarcia@gmail.com (H.G.); jesus.cuadrado@ehu.eus (J.C.); j.osa@ehu.eus (J.L.O.) \\ 2 Business Organization Department, University of the Basque Country (UPV/EHU), \\ 48940 Leioa Vizcaya, Spain \\ * Correspondence: m.zubizarreta@ehu.eus; Tel.: +34-943-01-86-60
}

Received: 26 November 2018; Accepted: 17 December 2018; Published: 21 December 2018

\begin{abstract}
A new structural typology of a hybrid purlin, made of type $C$ cold steel and rectangular laminated wood (SWP), is presented in this paper. As a result, improvements on the most commonly used steel purlins are achieved, by substituting some of the steel sections for wooden sections. Although the wooden section is weaker and has a lower elastic modulus than the steel, the overall dimensions of the SWP are no larger than the type $C$ steel purlin. In comparison with the steel ones, SWP purlins achieve a far better performance in terms of sustainability and are of lower weight, so less material will be needed for the main structure of the building. The behavior of each material in its position and the improvements in terms of sustainability and lower weight are analyzed as a function of span length, slope, and design load. To do so, the influence of both tensile stress and deformation design criteria in each section and the influence of those criteria on the choice of material and the lengths of each section are all examined. Finally, a design guide for the SWPs is presented that applies the proposed technical specifications.
\end{abstract}

Keywords: sustainability; wooden structures; steel structures; design guide

\section{Introduction}

The construction industry is one of the principal drains on natural resources and energy; it is responsible for one-third of global greenhouse gases [1] and for the consumption of up to $40 \%$ of all energy [2]. The same sector is also responsible for the consumption of $30 \%$ of the world's resources and $12 \%$ of existing water resources, besides producing between $30-40 \%$ of the residues that end up in the landfill. Many of the actions in this sector concentrate on the use of materials with higher sustainable rates, in the broadest sense; in other words, materials that are recyclable, reusable, or naturally renewable, as in the case of wood-based materials [3-8]. The switch over to certain materials takes time and may not be globally achieved, although the process continues its gradual development, despite powerful lobbying against any disruption to industrial production. Firms should nevertheless continue to adapt to demand in society through product development, while striving to incorporate these new environmental requirements in their products.

Accordingly, different models have been developed to analyze the sustainability of buildings and the different materials and components that compose them [9-14]. Several works have also been conducted to assess global sustainability and the costs of the most common structural (concrete, steel, and wood) typologies among other parameters. The study by Caruso et al. stands out, in which they propose a methodology for the comparative evaluation of the environmental sustainability of building structures based on LCA (life-cycle assessment) [15]. 
In this regard, the tendency at present in the construction industry is to use wood as a sustainable structural material [16-20]; government schemes increasingly incentivize the use of wooden structures among engineers and architects, as reported with great clarity in the studies of Balasbaneh and Marsono [21-23]. In addition, Stocchero at al. [24], among others, clearly demonstrated that the proposed reductions in carbon emissions are obtained much earlier in cities where structural typologies in new urban development plans are built of wood.

Wood is a well-known natural material. In its growth, through photosynthesis, trees fix $\mathrm{CO}_{2}$ releasing oxygen to produce the molecular structures of fibrous woody material. In other words, wood is a material that nature produces from chemical reactions with sunlight and water in which $\mathrm{CO}_{2}$ (one of the main causes of the greenhouse effect) is also fixed in the wood as it grows. On average, a typical tree, by means of photosynthesis, absorbs the equivalent of one ton of $\mathrm{CO}_{2}$ per cubic meter of wood. The $\mathrm{CO}_{2}$ fixed during the life of a tree and stored in the processed wood product plays a very important role in the efficiency of forest sinks, extending the period in which the carbon dioxide is stored and therefore not in the atmosphere. All of the above means that wood has a negative carbon footprint that is beneficial for the environment. Even when the useful life of structural wood ends, it is still a material that can be easily reused in other products such as doors, windows, etc. [25]. However, the natural decomposition of non-reusable wood should be avoided by promoting its combustion in cogeneration plants $[26,27]$.

Buildings made of wooden structures, although the most appropriate from the viewpoint of environmental sustainability [28], entail the consideration of dimensional limitations. In addition, further multidisciplinary research is required on this material considering the gaps in our knowledge [29]. Nevertheless, this type of research is reflected in the book Tackle Climate Change-Use Wood to expand sustainable forestry and forest products [30]. The authors of this work propose the concept of hybrid combinations of different structural materials and its application, along similar lines to García et al. [31,32], but rather than from an economic perspective, through a combination of sustainability and geometry. Hence, the decision to intersperse steel sections with wooden sections.

A preliminary review of the different parts of the main structures of a building where these combinations would be possible (pillars, beams, and slabs) yielded disproportionate dimensions. In other words, the wooden sections specified by standard calculations would have to be much larger than the steel sections. It was therefore concluded that this new concept could not reasonably be applied to the main structures. However, in the analysis of secondary structures such as lightweight roof purlins, the dimensional results between cold-formed steel purlins and laminated wood purlins were very similar. The initial proposal of combined steel and wood structural sections applied to these secondary structures developed into the SWP, presented in Figure 1. In our study, Glued Laminated Timber or glulam, of the Pinus radiata species, was selected because it is a very common product in Spain, with an abundant supply available from timber merchants.

The general dimensions of the sections that would otherwise be formed exclusively of steel structures can be maintained or reduced with the wooden sections incorporated in the SWP purlins of sufficient strength and rigidity to replace the steel sections.

A series of cases were studied (seeking to cover the majority of existing roofs) in which the $C$ shaped sections of cold-formed steel were replaced at strategic points by rectangular sections of laminated wood, in such a way that the two materials formed a solid joint. As will be described later on, three types of joints were dimensioned that covered all the cases analyzed in this study.

In this work, an analysis is firstly proposed of the behavior of the joint between the two materials (steel and wood) in the SWP purlins, as a function of the applied load, the distance between supports, and the slope of the roof. 


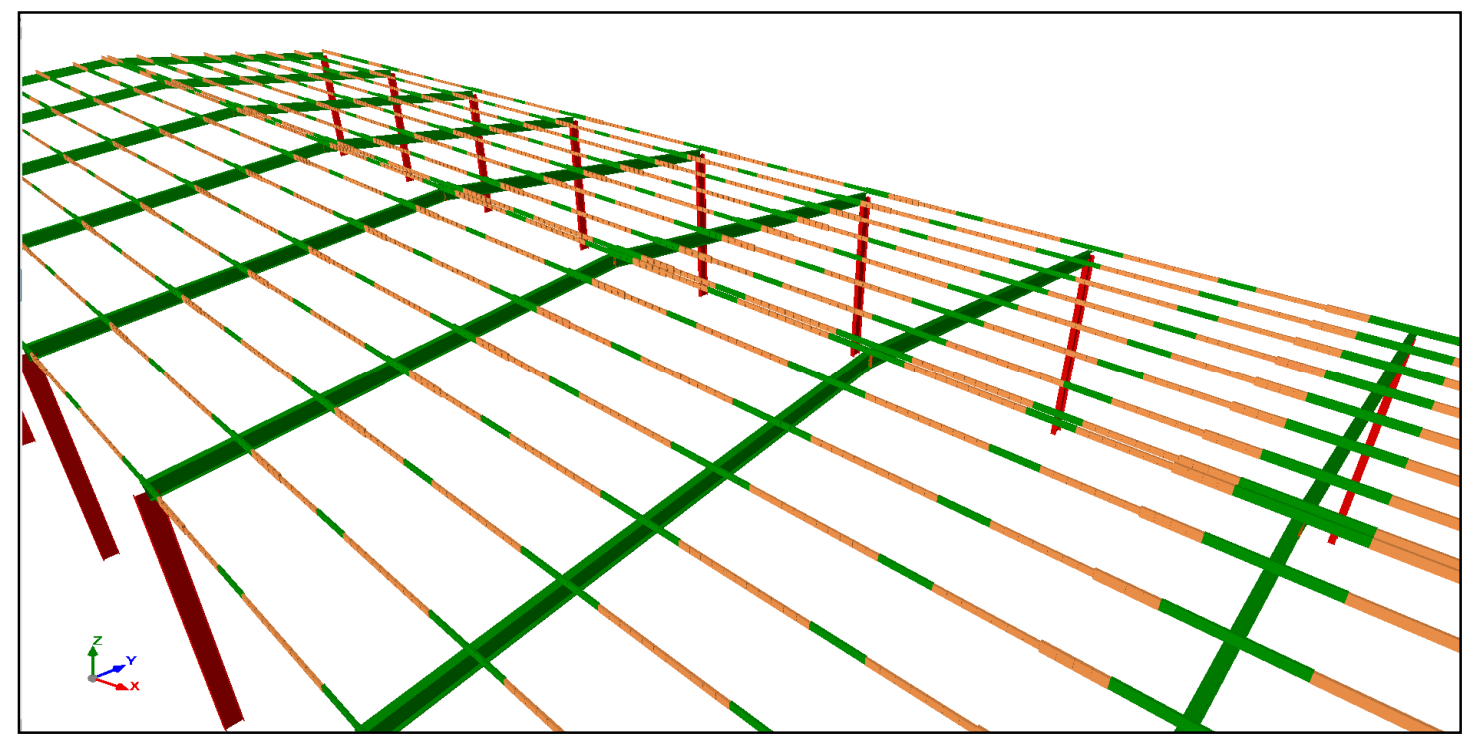

Figure 1. Lightweight SWP-type roofing purlins.

Secondly, an analysis is performed of the improvements obtained with the SWP purlins from the viewpoint of environmental sustainability, according to the applied load, the distance between the supports and the angle of the roof. To do so, similar criteria to those in the studies of Cuadrado et al. [4] and Canto-Perello et al. [33] will be used.

Thirdly, the intention is to analyze reductions or otherwise in the weight of this new structural typology as a function of the applied load, the distance between supports and the slope of the roof. This point of view is very important for the structures that will support the SWP purlins. If lightweight roofs can be further reduced in weight, they will directly affect the amount of material to be used in the main structure.

Finally, confidence of the important improvements achieved with this new structural typology, especially in terms of sustainability, and with an easily assembled structure, a SWP design guide is presented using the proposed technical specifications, with which the purlins can be rapidly dimensioned.

\section{Materials and Methods}

Nowadays, the separation between frames in steel structures and wooden structures is usually similar; they are usually no less than $6.5 \mathrm{~m}$ and no greater than $8.5 \mathrm{~m}$. Although the roof slopes are of a more varied range, they will not in most cases exceed 35\%. In addition, the separation between roof purlins depends directly on the resistance of the roofing component, typically sandwich panels. The separation is usually between 1.25 and $2.5 \mathrm{~m}$ and the weights of the roofing materials can range from $9 \mathrm{~kg} / \mathrm{m}^{2}$ for simple plates to almost $20 \mathrm{~kg} / \mathrm{m}^{2}$ for sandwich panels.

Live loads on lightweight roofs for most geographical areas and structural forms in Spain that limit the calculations will mainly be snow (set in this study at a maximum of $70 \mathrm{~kg} / \mathrm{m}^{2}$ ) and wind loading (a maximum of $100 \mathrm{~kg} / \mathrm{m}^{2}$ ). A maintenance overload of $40 \mathrm{~kg} / \mathrm{m}^{2}$ is considered for areas with little snow and no wind, which is not combined with other overloads. In view of the above, the study was conducted over span lengths ranging between 6.5 and $8.5 \mathrm{~m}$ and roof slopes ranging between 0 and $35 \%$, for load-bearing calculations of between 85 and $355 \mathrm{~kg} / \mathrm{m}^{2}$.

As previously mentioned in the introduction, wood was chosen due to its excellent behavior in terms of environmental sustainability as well as other aspects such as acoustics and even fire resistance [34]. There are many lines of research on this last point, as it is not easy to predict what will happen to wood in cases of fires at temperatures that differ from standard values [35]. In this regard, 
Hopkin proposed a very interesting method [36]. However, it is worth noting that fire resistance can be further improved through appropriate flame-retardant treatments with special surface treatments [37].

The metallic purlins of lightweight roofs are usually laminated in hot type IPE or cold formed type $\mathrm{C}$ or $\mathrm{Z}$ steel. The two types can fulfill the same functions, normally the use of one type or another is influenced by the size of the construction company in charge of the works. If the construction company has the capacity, it might consider building the IPE purlins in its own workshops, but if that capacity is unavailable, the manufacture of the purlins is usually outsourced and will tend to be type $\mathrm{C}$ or Z steel [38]. In this study, it was decided to improve the cold-formed type C purlins, because they are most suitable for the proposed SWP typology. In the case of sloping roofs, following standard practice, the purlins will be constructed with cables in the middle, which function as a supporting element for the weakest axis.

The 'Cype 3D' software package was used to calculate tensile stress and deformation in the purlins. Cype 3D performs three-dimensional (3D) structural calculations on bar-type elements at their intersections and all data inputs and the projected results are generated in the form of graphic outputs. Figure 2 can be useful for explaining the methodology when designing this new structural typology. For each of the 60 cases under analysis, the purlin was first modeled in Cype, constructed of four spans, and then each span was discretized into 0.25 -m stretches.

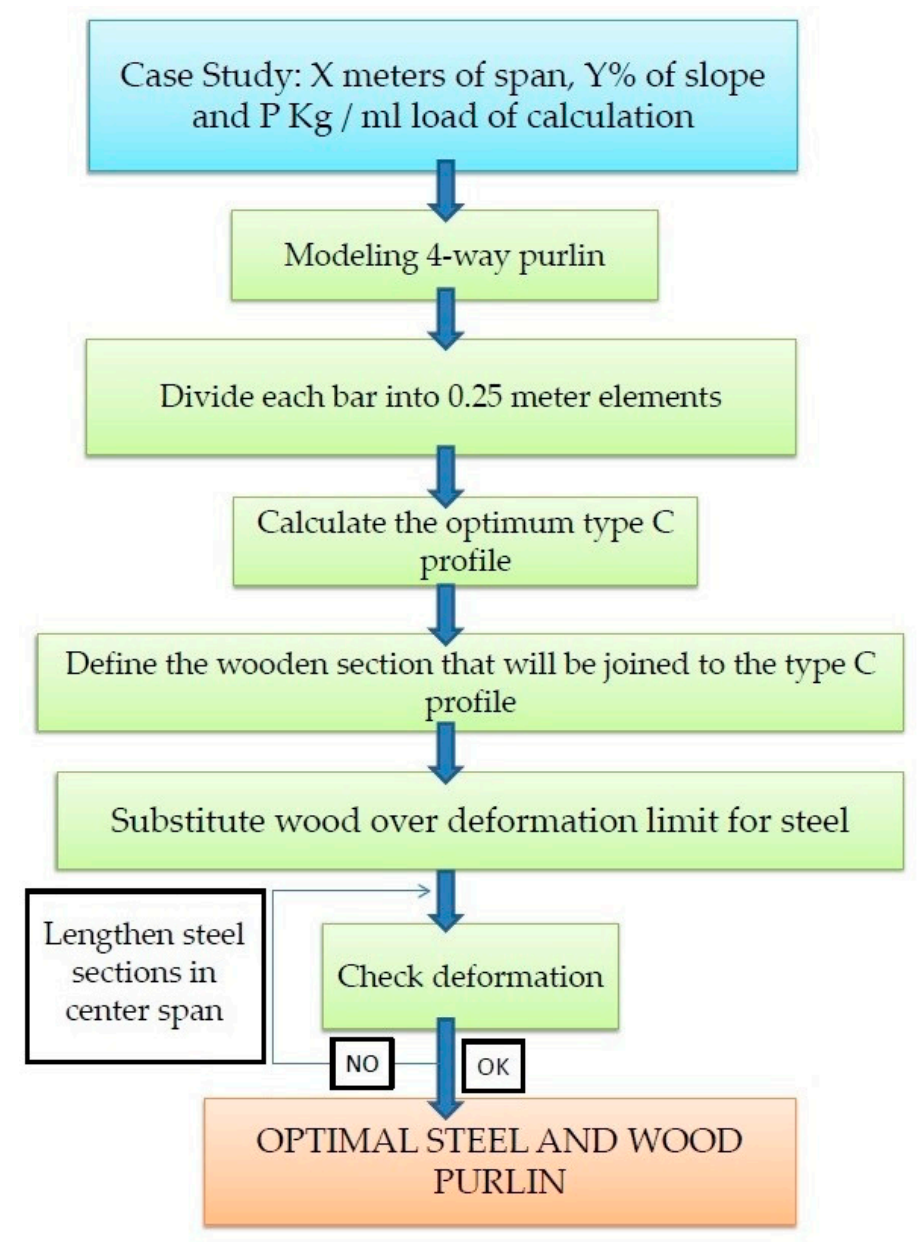

Figure 2. Methodology.

The reason why four-span purlins were modeled is that, in reality, the lightweight roof purlins are usually joined in such a way that they can be considered continuous beams with as many supports as are found in the framework of the building. Structural calculations of the purlins, ranging from one span up to seven spans, led to the clear conclusion that the differences were depreciable at four or more 
spans. Dimensioning with continuous purlins of four spans was therefore considered to be sufficiently precise. It was likewise decided to discretize the purlins in components of $0.1,0.15,0.2,0.25,0.3,0.35$, $0.4,0.45$, and $0.5 \mathrm{~m}$, which yielded the best and the most similar results in the first four cases (from $0.1 \mathrm{~m}$ to $0.25 \mathrm{~m}$ ). The results were not sufficiently defined in the larger sizes of discretization, so the purlins were therefore discretized in elements of $0.25 \mathrm{~m}$.

After the modeling process, the cold formed type $C$ profile was dimensioned for the entire purlin; in most cases, the dimensioning was defined in the supports due to the negative moments that were produced.

Having calculated the type $C$ profile, a rectangular section of wood was formed that fitted exactly into the type $C$ profile, replacing the steel elements where possible (generally in the middle of the spans, not in contact with the supports).

Finally, the deformation limit of L/300 was verified, starting from center span and, where over the limit, the wooden section was replaced by steel. Once the calculations of the purlin met all the design criteria, it was considered to be an optimum type of SWP purlin. The whole process is depicted in Figure 2.

\section{Results and Discussion}

What follows is a description of the way in which it was decided to breakdown a continuous purlin; a six-span purlin is represented in Figure 3a. As can be seen, it has been divided into two types: V1 and V2. V1 corresponds to the purlins at the extreme ends of the span plus half of the adjacent ones (Figure $3 b$ ) and V2 runs from the center span to the following center span of the inner purlins (Figure 3c).

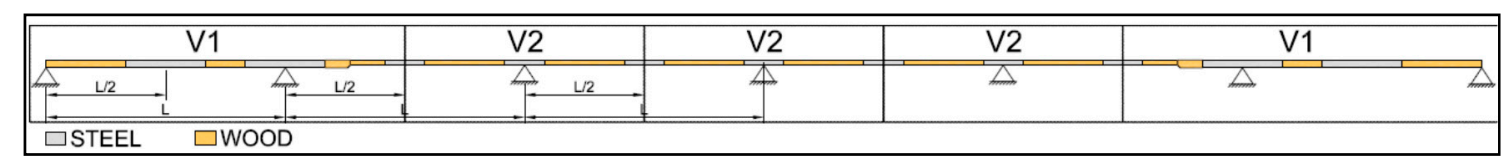

(a)

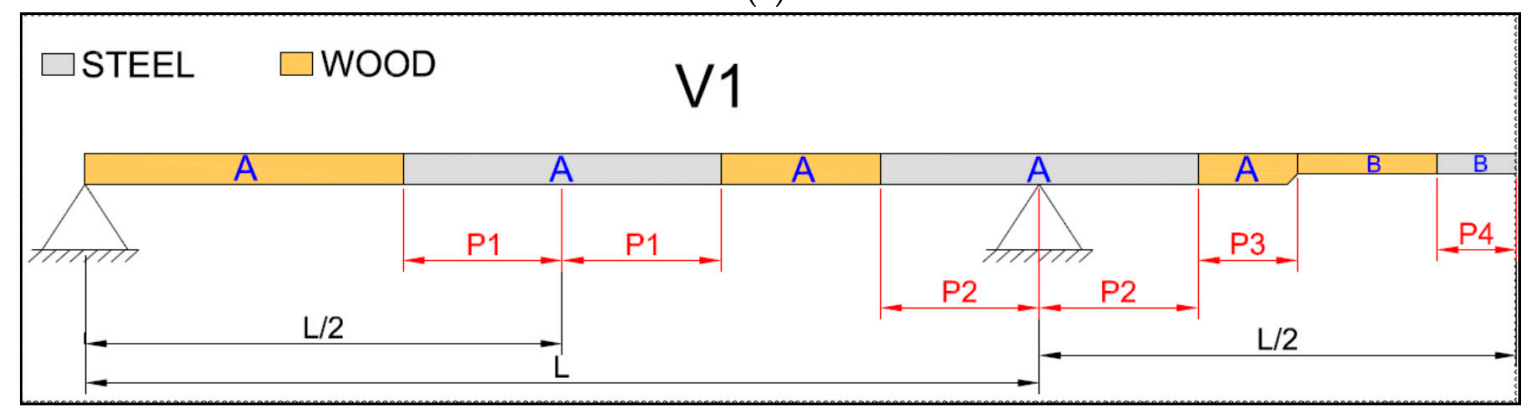

(b)

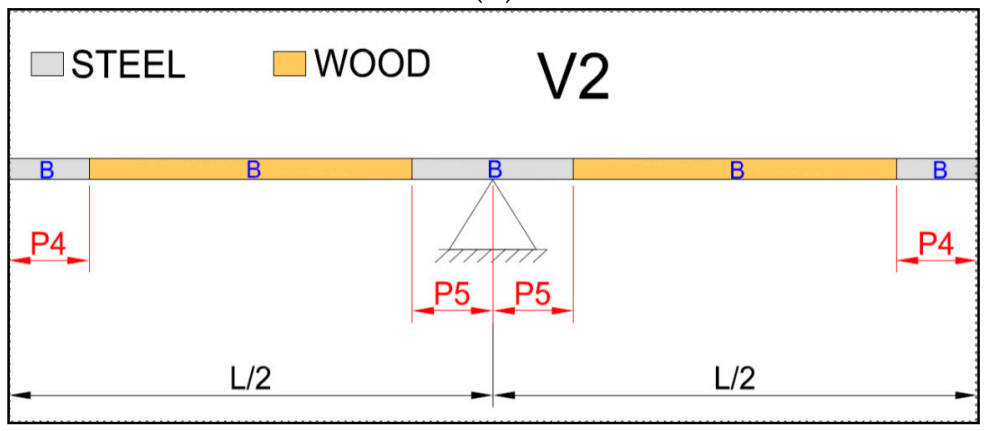

(c)

Figure 3. (a) Purlins type V1 and V2. (b) Purlin type V1. (c) Purlin type V2. 
The parameters that define the V1 purlin are $\mathrm{P} 1, \mathrm{P} 2, \mathrm{P} 3$, and $\mathrm{P} 4$, all of which are percentage lengths of the span. There are in addition two section sizes-A and B:

- $\quad \mathrm{P} 1$ is the steel portion in the middle of the extreme span (section size A)

- $\quad \mathrm{P} 2$ is the steel portion in the second of the supports (section size A)

- $\quad \mathrm{P} 3$ is the wooden portion located in the second span (the last of the A-size portions)

- $\quad \mathrm{P} 4$ is the steel portion in the middle of the second span (section size B)

The parameters that define the V2 purlin are $\mathrm{P} 4$ and $\mathrm{P} 5$, all of which in percentage parts along the length of the span. In addition, type B will be the only section size:

- $\quad \mathrm{P} 4$ is the steel portion in the middle of the interior spans (section size B)

- $\quad$ P5 is the steel portion in the inner supports (section size B)

The following diagrams of bending moments and deformation resulting from the calculation of the purlins are similar to those in Figure 4.

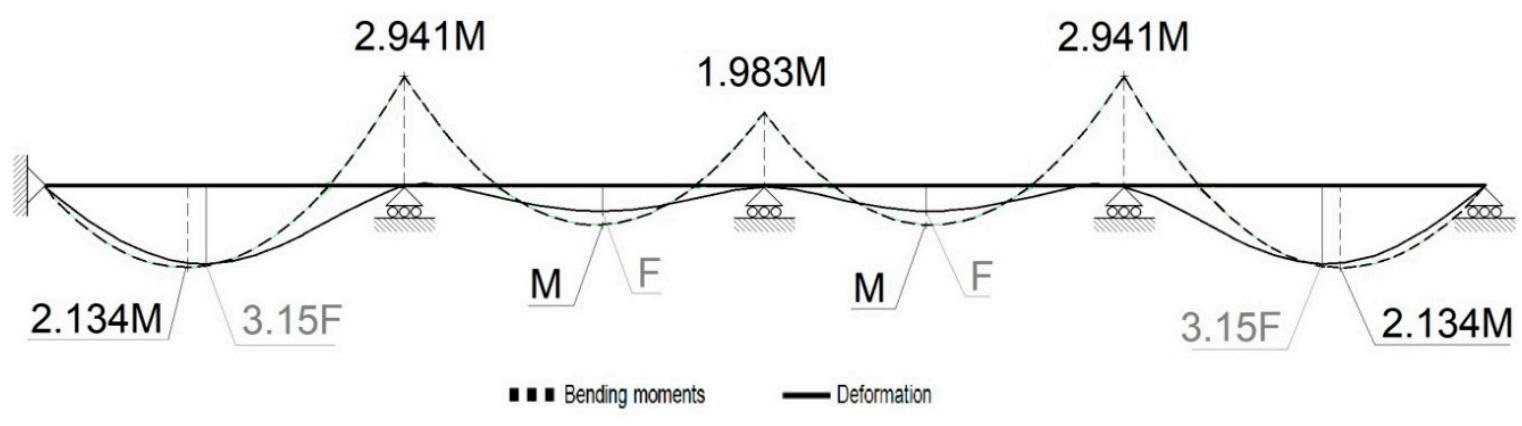

Figure 4. Inner purlin tensile stresses.

Analyzing the parts corresponding to the bending moment in these diagrams, it may be seen that the minimum design moment $(\mathrm{M})$ is in the center of the interior spans, the maximum design moment $(2.941 \times \mathrm{M})$, in the second of the supports, and a value somewhat lower than the maximum value $(2.134 \times \mathrm{M})$ in the center of the first span.

Analyzing the deformation, it can be seen that the minimum deformation appears in the interior spans $(\mathrm{F})$ and the maximum in the first spans $(3.15 \times \mathrm{F})$.

Under the same span length, the determining design factor will change from deformation in cases of low load to tensile stress as the loading increases.

Under the same loads, the determining design factor will change from tensile stress in cases of short separations between supports to deformation as the separation increases.

Tables 1 and 2 compile the $\mathrm{P}$ parameters results obtained regarding the roof slopes, design load and span.

In cases where stress is the determining design factor, but the cases are otherwise of very low tensile stress (where profiles or small sections are required), type $C$ steel profiles tend to support the design stress better, as the inertia of the corresponding wooden section is not so very different, although there is a difference between the elastic limits of the two materials. 
Table 1. P Parameters of $0^{\circ}$ slopes.

\begin{tabular}{|c|c|c|c|c|c|c|c|c|c|c|c|}
\hline & Slope $=$ & 0 & & & & & & & & & \\
\hline & $\begin{array}{c}\text { Design Load } \\
(\mathrm{Kg} / \mathrm{mL})=\end{array}$ & 85 & 115 & 145 & 175 & 205 & 235 & 265 & 295 & 325 & 355 \\
\hline \multirow{5}{*}{$6.5 \mathrm{~m}$} & $P 1(m)=$ & 1 & 1.75 & 1.25 & 1 & 1.25 & 1.25 & 0.5 & 0.75 & 0 & 1 \\
\hline & $\mathrm{P} 2(\mathrm{~m})=$ & 0 & 0.25 & 0.25 & 0.25 & 0.5 & 0.75 & 0 & 0 & 0 & 0.5 \\
\hline & $\mathrm{P} 3(\mathrm{~m})=$ & 0.75 & 1 & 1 & 1 & 0.25 & 0.5 & 1 & 0.75 & 0.75 & 0.5 \\
\hline & $\mathrm{P} 4(\mathrm{~m})=$ & 0.25 & 0.5 & 0.25 & 0 & 0 & 0 & 0 & 0 & 0 & 0 \\
\hline & P5 $(\mathrm{m})=$ & 0.25 & 0.5 & 1 & 0.75 & 0.5 & 0.5 & 0.5 & 0.25 & 0.5 & 0.5 \\
\hline \multirow{5}{*}{$7.5 \mathrm{~m}$} & $\mathrm{P} 1(\mathrm{~m})=$ & 1.25 & 2 & 1.75 & 2 & 1 & 1.5 & 0.75 & 1 & 1.25 & 0.75 \\
\hline & $\mathrm{P} 2(\mathrm{~m})=$ & 0.25 & 0.5 & 0.5 & 0.75 & 0 & 0.25 & 0.25 & 0.5 & 0.5 & 0.25 \\
\hline & $\mathrm{P} 3(\mathrm{~m})=$ & 0.75 & 0.75 & 0.5 & 0.5 & 1 & 1 & 1 & 0.25 & 0.25 & 0.5 \\
\hline & $\mathrm{P} 4(\mathrm{~m})=$ & 0.5 & 0.25 & 0 & 0 & 0 & 0 & 0 & 0 & 0 & 0 \\
\hline & P5 $(m)=$ & 0.5 & 0.75 & 0.25 & 0.75 & 0.5 & 0.75 & 0.5 & 0 & 0 & 0.25 \\
\hline \multirow{5}{*}{$8.5 \mathrm{~m}$} & $P 1(m)=$ & 2.5 & 1.75 & 1.25 & 2.25 & 1.5 & 1 & 0.25 & 0.75 & 1.25 & 1 \\
\hline & $\mathrm{P} 2(\mathrm{~m})=$ & 0.5 & 1 & 0.25 & 0.25 & 0.25 & 0.25 & 0.25 & 0.25 & 0.25 & 0.75 \\
\hline & $\mathrm{P} 3(\mathrm{~m})=$ & 1.25 & 1.25 & 1.25 & 1 & 1 & 0.5 & 0.5 & 0.5 & 0.5 & 0.25 \\
\hline & $\mathrm{P} 4(\mathrm{~m})=$ & 1 & 0.5 & 0.25 & 0.25 & 0 & 0 & 0 & 0 & 0 & 0 \\
\hline & P5 $(\mathrm{m})=$ & 1.25 & 1 & 0.75 & 0.75 & 0.75 & 0 & 0.25 & 0 & 0.25 & 0.25 \\
\hline
\end{tabular}

Table 2. P Parameters of $20^{\circ}$ slopes.

\begin{tabular}{|c|c|c|c|c|c|c|c|c|c|c|c|}
\hline & Slope $=$ & 20 & & & & & & & & & \\
\hline & $\begin{array}{c}\text { Design Load } \\
(\mathrm{Kg} / \mathrm{mL})=\end{array}$ & 85 & 115 & 145 & 175 & 205 & 235 & 265 & 295 & 325 & 355 \\
\hline \multirow{5}{*}{$6.5 \mathrm{~m}$} & $P 1(m)=$ & 1.75 & 0.75 & 1.25 & 0.75 & 0 & 0 & 0 & 0.5 & 0.25 & 0.25 \\
\hline & $\mathrm{P} 2(\mathrm{~m})=$ & 0.5 & 0 & 0.25 & 0.5 & 0 & 0 & 0.25 & 0.25 & 0.25 & 0.25 \\
\hline & $\mathrm{P} 3(\mathrm{~m})=$ & 0 & 0.25 & 0.25 & 0.25 & 0.5 & 0.5 & 0 & 0 & 0.25 & 0.25 \\
\hline & $\mathrm{P} 4(\mathrm{~m})=$ & 0 & 0 & 0 & 0 & 0 & 0 & 0 & 0 & 0 & 0 \\
\hline & P5 $(\mathrm{m})=$ & 0 & 0 & 0.25 & 0.25 & 0.5 & 0.25 & 0 & 0 & 0 & 0 \\
\hline \multirow{5}{*}{$7.5 \mathrm{~m}$} & $P 1(m)=$ & 1.75 & 1.75 & 0 & 0.5 & 1 & 0.25 & 0 & 0 & 0 & 0 \\
\hline & $\mathrm{P} 2(\mathrm{~m})=$ & 0.5 & 0.5 & 0 & 0 & 0 & 0.25 & 0 & 0 & 0 & 0.25 \\
\hline & $\mathrm{P} 3(\mathrm{~m})=$ & 0.5 & 0.25 & 0.5 & 0.75 & 0 & 0.25 & 0.5 & 0.5 & 0.25 & 0.25 \\
\hline & $\mathrm{P} 4(\mathrm{~m})=$ & 0 & 0 & 0 & 0 & 0 & 0 & 0 & 0 & 0 & 0 \\
\hline & P5 $(m)=$ & 0.5 & 0.25 & 0.25 & 0.5 & 0 & 0 & 0 & 0.25 & 0 & 0 \\
\hline \multirow{5}{*}{$8.5 \mathrm{~m}$} & $P 1(m)=$ & 2.5 & 0.5 & 1.25 & 1.25 & 0.25 & 0 & 0 & 0.25 & 0 & 0 \\
\hline & $\mathrm{P} 2(\mathrm{~m})=$ & 0.5 & 0 & 0 & 0 & 0 & 0 & 0 & 0.5 & 0 & 0 \\
\hline & $\mathrm{P} 3(\mathrm{~m})=$ & 0.25 & 0.75 & 0 & 0.25 & 0.5 & 0.25 & 0.5 & 0 & 0.5 & 0.5 \\
\hline & $\mathrm{P} 4(\mathrm{~m})=$ & 0 & 0 & 0 & 0 & 0 & 0 & 0 & 0 & 0 & 0 \\
\hline & P5 $(\mathrm{m})=$ & 0.25 & 0.5 & 0 & 0 & 0 & 0 & 0 & 0 & 0.5 & 0 \\
\hline
\end{tabular}

However, as soon as the profile or section has to be slightly increased in size, the differences between the main inertias of the type $C$ profile and the rectangular section change considerably (with a very high increase in the case of the rectangular section). This implies the presence of wooden sections in the majority of sections where the design criterion is tensile stress.

In contrast, steel purlins will form the predominant material in the sections where deformation is the determining design factor, as the elastic modulus of steel is practically 12 times greater than the elastic modulus of wood.

In the following sub-section, the graphs from the final design results are analyzed and their correlation with underlying reasoning will be verified. In Figures 5 and 6, the variable P represents the position of each material, the angles 0 and 20 indicate the slope of the cover, the design load refers to the overload or to the most unfavorable overload combination and in the $y$-axis shows the percentage value of the $P$ parameter regarding the span. 

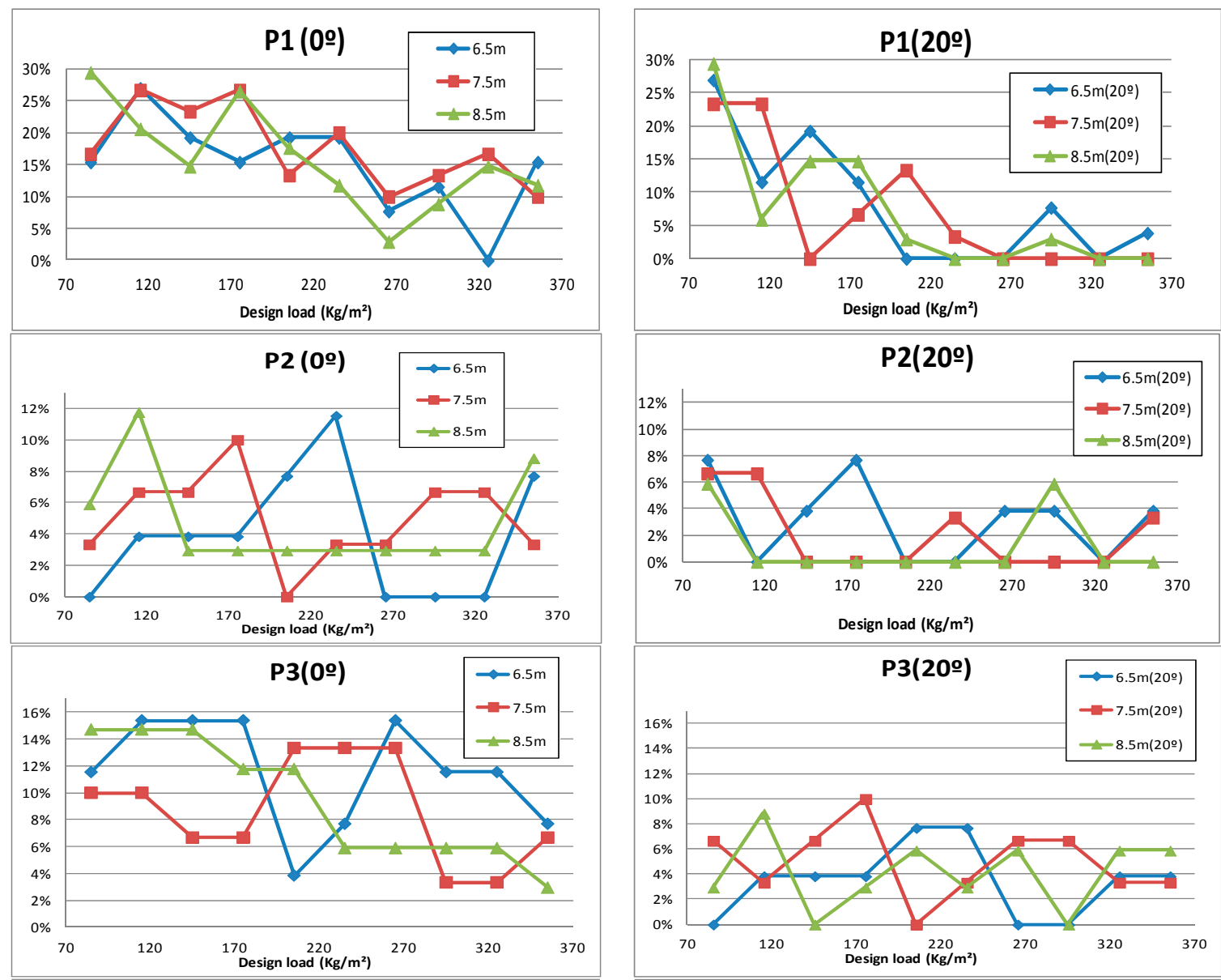

P4(0)

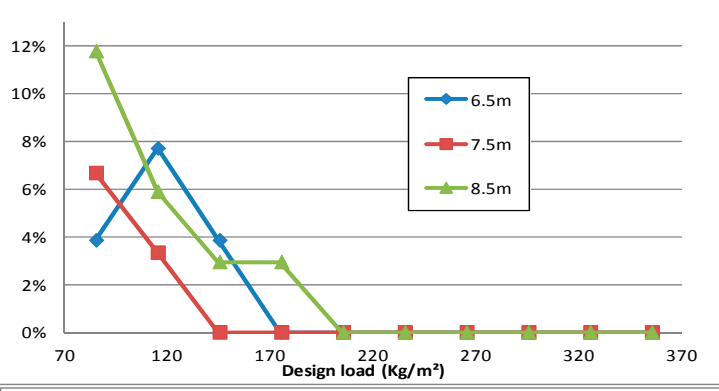

P4(20)

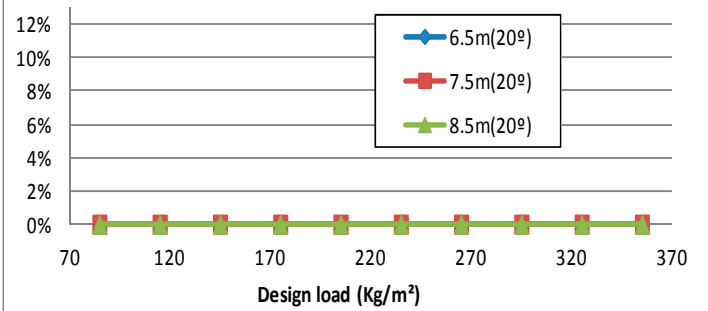

P5(0)
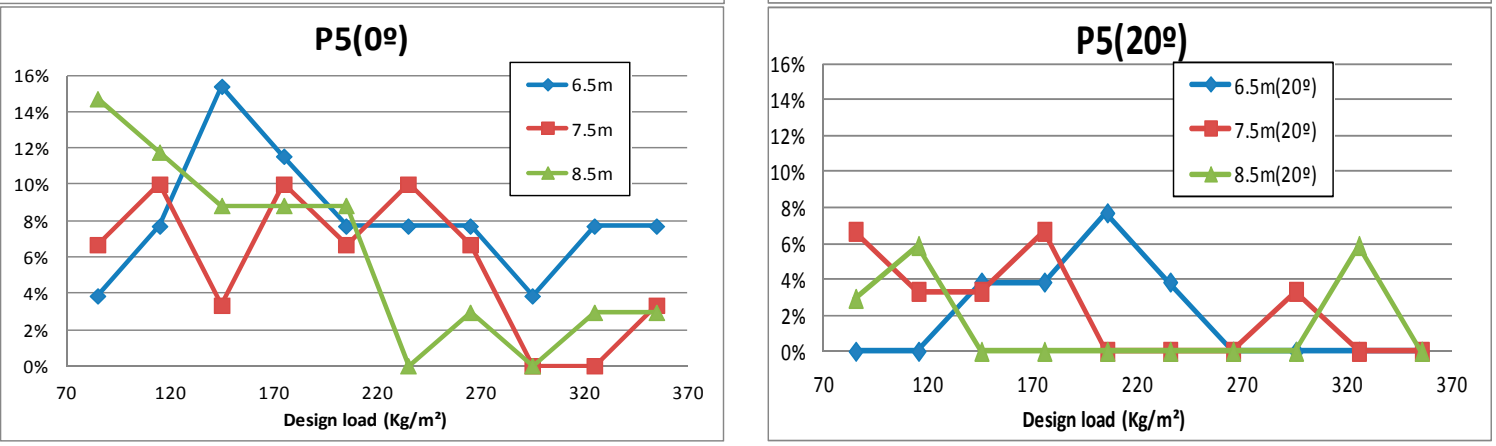

Figure 5. Comparison of the P parameters regarding the cover slope, design load and span lengths. 

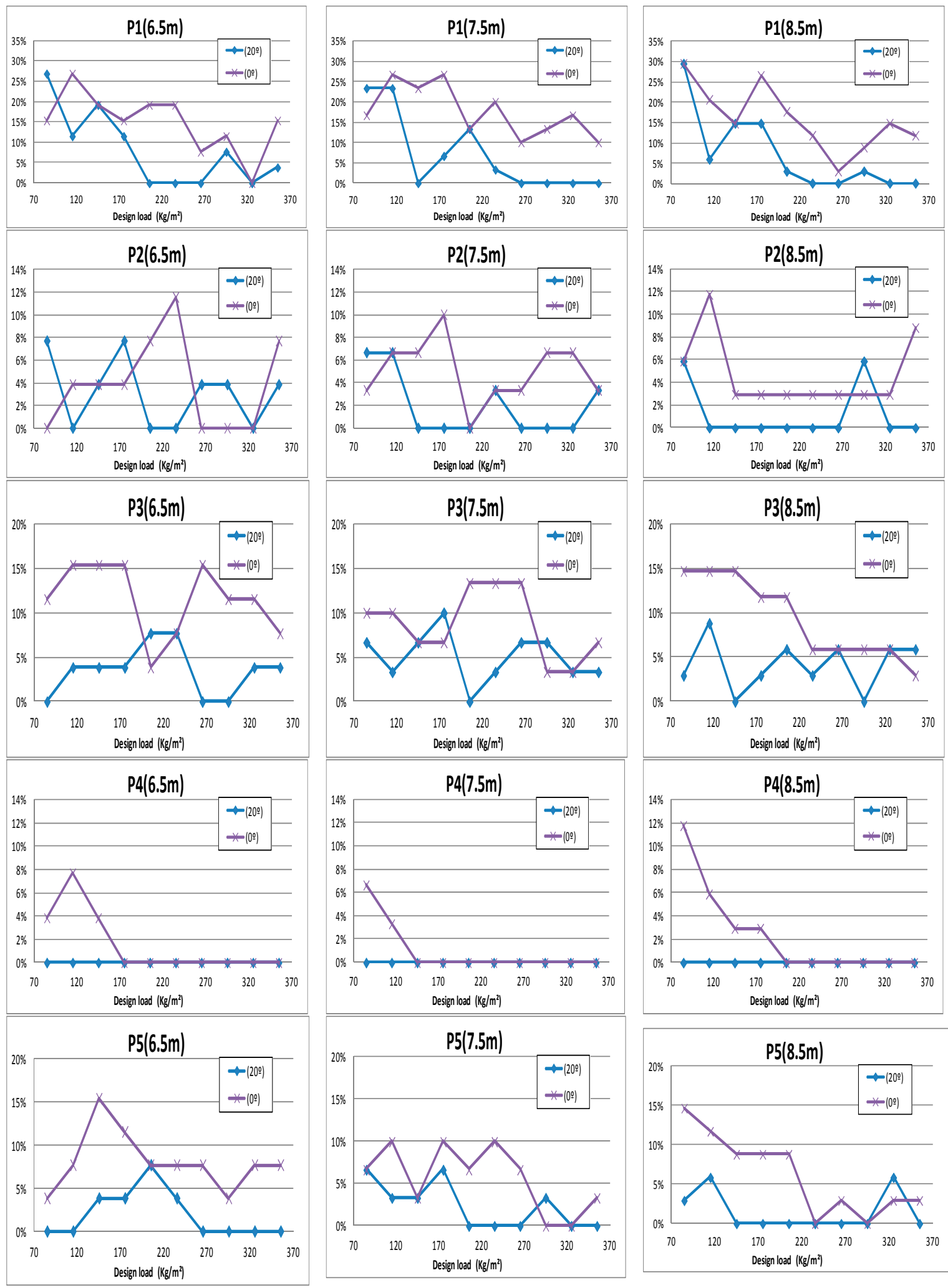

Figure 6. Comparative parameters according to roof slopes.

\subsection{Behavior of Parameters as a Function of Span Length and Loading}

The graphs presented in Figure 5 show the influence of the span length, cover slope and loading on the ratio of $\mathrm{P}$ parameter and span. 
- P1: as the loading increases its values decrease (smaller steel sections), complying with the design criteria for tensile stress.

- P1: as the span length increases, its values increase (longer steel sections), complying with the design criteria for deformation. However, those parameters are not so clear for the $8.5-\mathrm{m}$ spans with high loads, because in those cases the design section A is defined by the tensile stress in the second support.

- P1: in comparison with the other parameters, P1 has higher values, which reflects the importance of the deformation in the design of the first span of the purlins.

- P2: has very small values, but a slightly decreasing tendency is appreciated, complying with the design criterion for tensile stress.

- P2 and P3: an antagonistic behavior is observed, which indicates that the length of section A in the second span is always similar; the changes affect the portions of steel and wood.

- P4: in most cases, section B is defined by the design criteria of the intermediate supports (previous point), so that where the tensile stress is much lower, as in the sections corresponding to P4, wooden sections will be inserted. Only under very small loads on very long span lengths will the design criterion of deformation predominate, in which case the section corresponding to P4 will be made of steel.

- P5: the design criterion is clearly and exclusively one of tensile stress and as the loading values and the span lengths increase, the tensile stress values decrease.

\subsection{Behavior of the Parameters as a Function of the Slope and the Load}

In turn, Figure 6 shows emphasizes the influence of the cover slope on the P parameter. A high influence of the support for the weak axis produced by the cables in the inter-spans is observed. The slope and the support imply a redistribution of the stress, reducing them along the main axis, but increasing them along the weak axis. Tables 3 and 4 show how sections A and B are needed for sloping roofs that are larger than those needed for flat roofs. As previously mentioned, this assumption implies a greater presence of wooden sections.

- P1: the design criterion of deformation is of less importance for sloped roofs. Much smaller steel sections will be needed than in flat roofs.

- P2: similar and very small values for flat and sloped roofs.

- P3: somewhat higher values for flat roofs.

- P4: the deformation criterion discussed in the previous point is no longer present and the sloped roofs always have zero values in the range under study.

- P5: somewhat lower values for sloped roofs.

Table 3. Cases under study.

\begin{tabular}{ccc}
\hline \multicolumn{3}{c}{ Design Load $(\mathrm{Kg} / \mathbf{m L})($ Arrow $<\mathrm{L} / \mathbf{3 0 0})$} \\
\hline $\mathbf{6 . 5} \mathbf{m}$ & $\mathbf{7 . 5} \mathbf{~ m}$ & $\mathbf{8 . 5} \mathbf{~ m}$ \\
\hline 85 & 85 & 85 \\
115 & 115 & 115 \\
145 & 145 & 145 \\
175 & 175 & 175 \\
205 & 205 & 205 \\
235 & 235 & 235 \\
265 & 265 & 265 \\
295 & 295 & 295 \\
325 & 325 & 325 \\
355 & 355 & 355 \\
\hline
\end{tabular}


Table 4. Dimensioning of sectional geometry and joint types for $0^{\circ}$ slopes.

\begin{tabular}{|c|c|c|c|c|c|c|c|c|c|}
\hline $0^{\circ}$ & STEEL & & & A & & & B & WOOD & \\
\hline \multirow{9}{*}{ 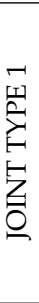 } & CF 120.2.0 & & & & & 115 & 85 & $116 \times 46$ & \multirow{9}{*}{ 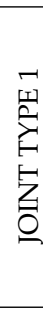 } \\
\hline & CF 120.2 .5 & & & & & & & $115 \times 45$ & \\
\hline & CF 120.3.0 & & & & 145 & & & $114 \times 44$ & \\
\hline & CF 140.2.0 & & & & & & & $136 \times 46$ & \\
\hline & CF 140.2.5 & & & & 115 & & & $135 \times 45$ & \\
\hline & CF 140.3.0 & & & & 175 & & & $134 \times 44$ & \\
\hline & CF 160.2.0 & 85 & 115 & & 145 & & & $156 \times 56$ & \\
\hline & CF 160.2.5 & & & & 205 & 235 & 175 & $155 \times 55$ & \\
\hline & CF 160.3.0 & & & & 145 & & & $154 \times 54$ & \\
\hline \multirow{9}{*}{ 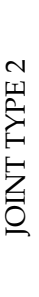 } & CF 180.2.0 & 145 & 85 & & & & & $176 \times 56$ & \multirow{9}{*}{ 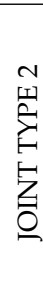 } \\
\hline & CF 180.2.5 & 115 & & & 265 & & & $175 \times 55$ & \\
\hline & CF 180.3.0 & & & & 205 & 235 & $17 !$ & $174 \times 54$ & \\
\hline & CF 200.2.0 & 175 & & & & & & $196 \times 56$ & \\
\hline & CF 200.2.5 & 205 & 145 & & 295 & 325 & & $195 \times 55$ & \\
\hline & CF 200.3.0 & 235 & 175 & & 355 & 265 & 05 & $194 \times 54$ & \\
\hline & CF 225.2.5 & 265 & 295 & $205 \quad 235$ & 295 & 325 & 355 & $220 \times 75$ & \\
\hline & CF 225.3.0 & 355 & & & & & & $219 \times 74$ & \\
\hline & CF 225.4.0 & & & & & & & $217 \times 72$ & \\
\hline \multirow{9}{*}{ 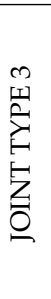 } & CF 250.2.5 & 325 & 265 & 205 & 295 & & & $245 \times 75$ & \multirow{9}{*}{ 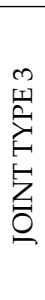 } \\
\hline & CF 250.3.0 & 295 & 325 & & 325 & 355 & & $244 \times 74$ & \\
\hline & CF 250.4.0 & & & & & & & $242 \times 72$ & \\
\hline & CF 275.2.5 & 235 & & & & & & $270 \times 75$ & \\
\hline & CF 275.3.0 & 355 & & & & & & $269 \times 74$ & \\
\hline & CF 275.4.0 & & & & & & & $267 \times 72$ & \\
\hline & CF 300.2.5 & 265 & & & & & & $295 \times 75$ & \\
\hline & CF 300.3.0 & 295 & 325 & & & & & $294 \times 74$ & \\
\hline & CF 300.4.0 & 355 & & & & & & $292 \times 72$ & \\
\hline
\end{tabular}

\subsection{Sustainability Analysis and Comparison of the SWP and the Steel Purlins}

As previously mentioned in the introduction, the Pinus radiata species of wood has been used in the dimensioning of this new structural typology. In this case, the carbon footprint associated with the production of each cubic meter is negative $(-781.96 \mathrm{~kg})$ [39], which means that for every cubic meter of wood that is produced, not only is some $\mathrm{CO}_{2}$ released into the atmosphere, but $781.96 \mathrm{~kg}$ of $\mathrm{CO}_{2}$ is retained. Taking into account that the density of this material is $500 \mathrm{~kg} / \mathrm{m}^{3}$, it may be concluded that the carbon footprint of one ton of Pinus radiata wood is $-1,563.92 \mathrm{~kg}$ of $\mathrm{CO}_{2}$.

In contrast, focusing on structural steel, the carbon footprint associated with the production of one ton of this material is clearly positive. Specifically, the carbon footprint of one ton of this material is $1932 \mathrm{~kg}$ of $\mathrm{CO}_{2}$ [40].

With these two datasets, the carbon footprint has been calculated for each case that is studied, both for the new structural typology 'steel + wood' and for the steel typology commonly used today. The reduction of the carbon footprint obtained with the SWP has been calculated with this information and the improvement in sustainability has been compared as a function of the distance between the frames, the roof slope, and the applied load (see Figure 7).

- In the entire range of cases analyzed in this study, there is a very large reduction of the carbon footprint of the SWPs in comparison with the steel purlins.

- The carbon footprint reduction of the SWP purlins in relation to the steel purlins increases as the slope increases, but tends to even out as the design load increases.

- The reduction of the carbon footprint in terms of applied loads shows a rising curve for all span lengths, but the longer the span length, the faster the rise.

- For the smallest loads (the start of the curves), the longer the span length, the greater the reduction in the carbon footprint. 

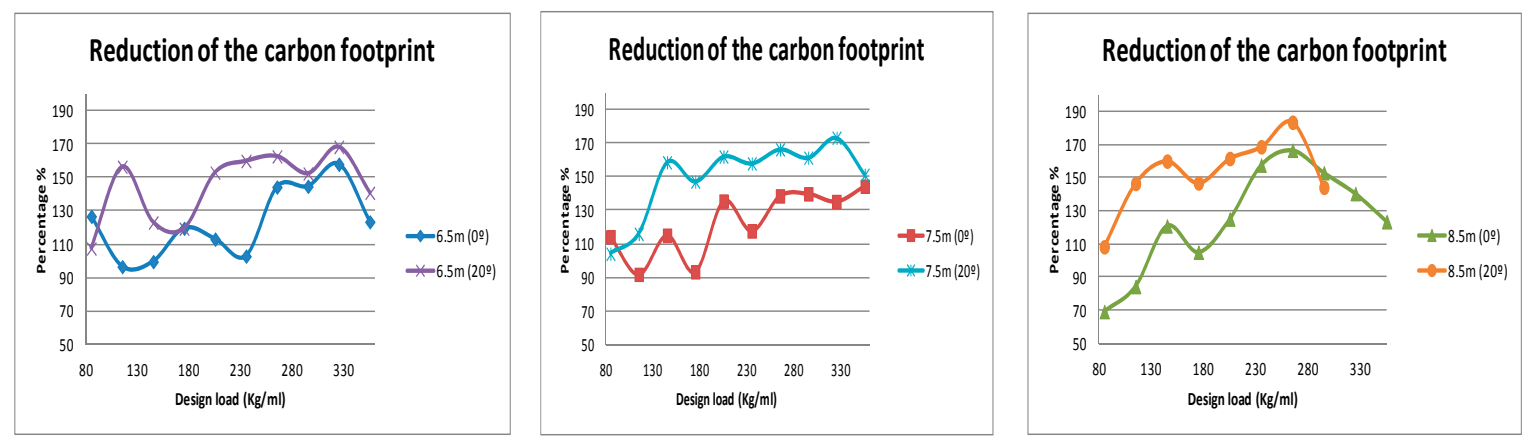

Figure 7. Comparisons of carbon footprints by span length and roof slope.

As an example, if the entire purlin consisted of type $C$ steel for a design load of $205 \mathrm{~kg} / \mathrm{mL}$, a separation of $7.5 \mathrm{~m}$ between frames and a roof slope of 20 degrees, the purlin would have a carbon footprint of $15.8 \mathrm{~kg}$ per meter. In the same case, the result for SWP-type purlins would be $9.83 \mathrm{~kg}$; a reduction of $162 \%$.

\subsection{Analysis and Comparison of the Weight between SWP-Type Purlins and Steel Purlins}

In practical terms, a reduction of the total weight of the purlins is achieved for the whole range of cases under study, which will also mean a saving in the main resistant structure of the building.

The saving in weight is more evident in the flat than in the sloped roofs and a slight tendency to reduce this saving in weight is seen as the loads increase.

The savings in weight are somewhat less in roofs with longer span lengths. (see Figure 8).
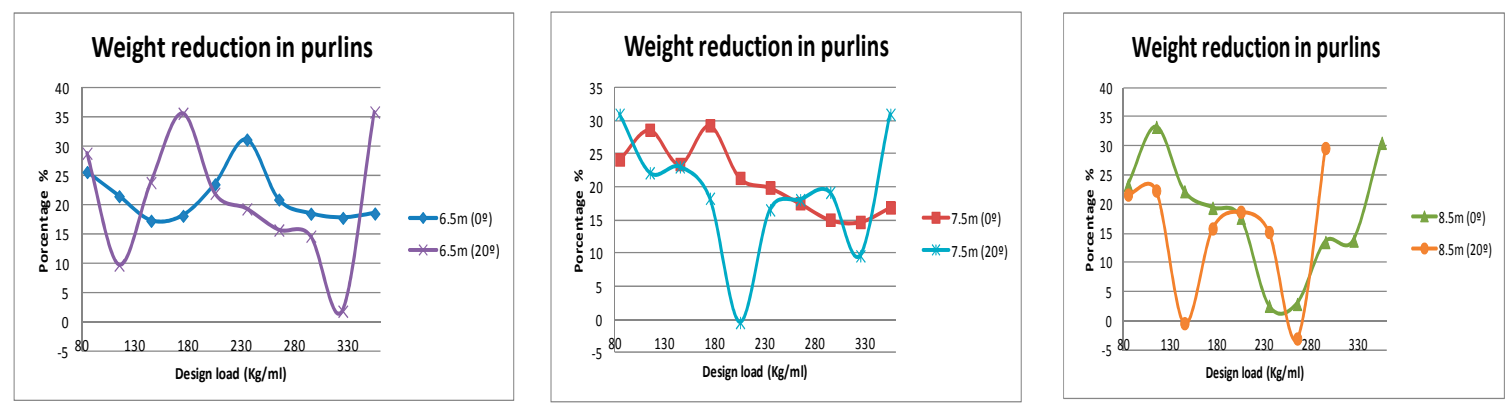

Figure 8. Comparison of the purlins by weight according to span lengths and roof angles.

\subsection{Design and Selection of the Joint Typology}

The steel-wood joint has been also taken into account in the development. Three joint types have been tailored design according to the purlins dimensions. Figures 9-11 show the dimensions of the joints, according the size of the $C$ type steel purlins.

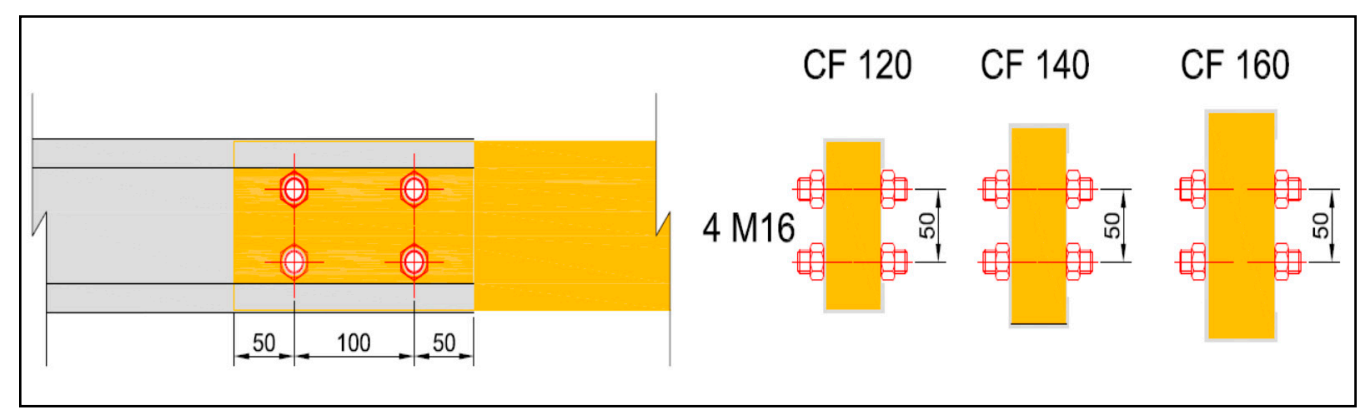

Figure 9. Joint type 1 (unit: $\mathrm{mm}$ ). 


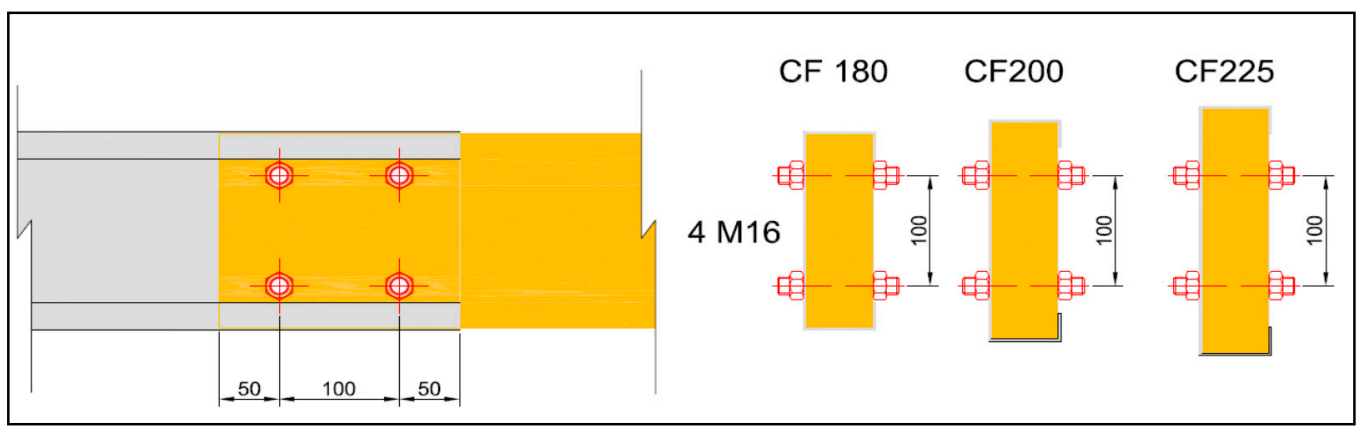

Figure 10. Joint type 2 (unit: $\mathrm{mm}$ ).

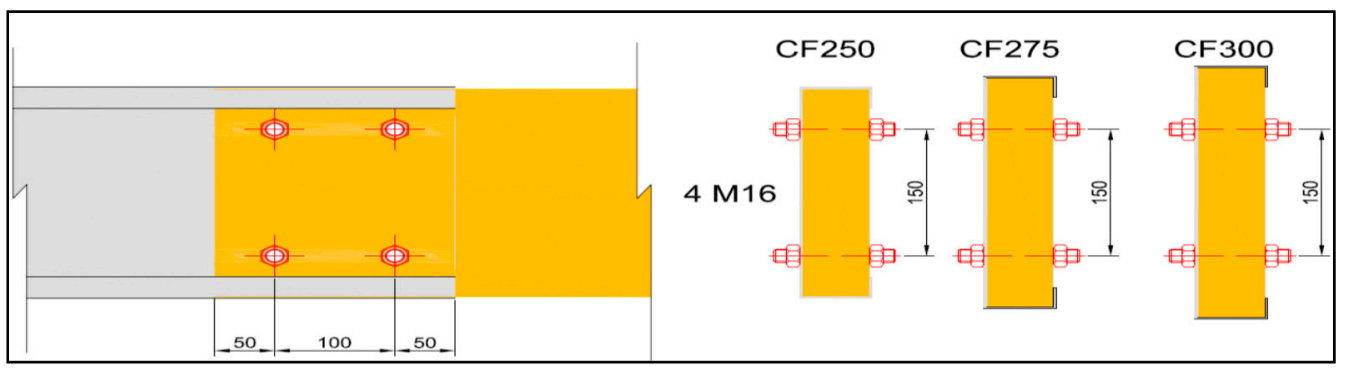

Figure 11. Joint type 3 (unit: $\mathrm{mm}$ ).

Table 3 introduces the color code that defines the design case according to the purling length and the loading. This code color enables the use of Tables 4 and 5, where the design load allowed for each design case is linked to each purling size and joint type.

Table 5. Dimensioning of sectional geometry and joint types for $20^{\circ}$ slopes.

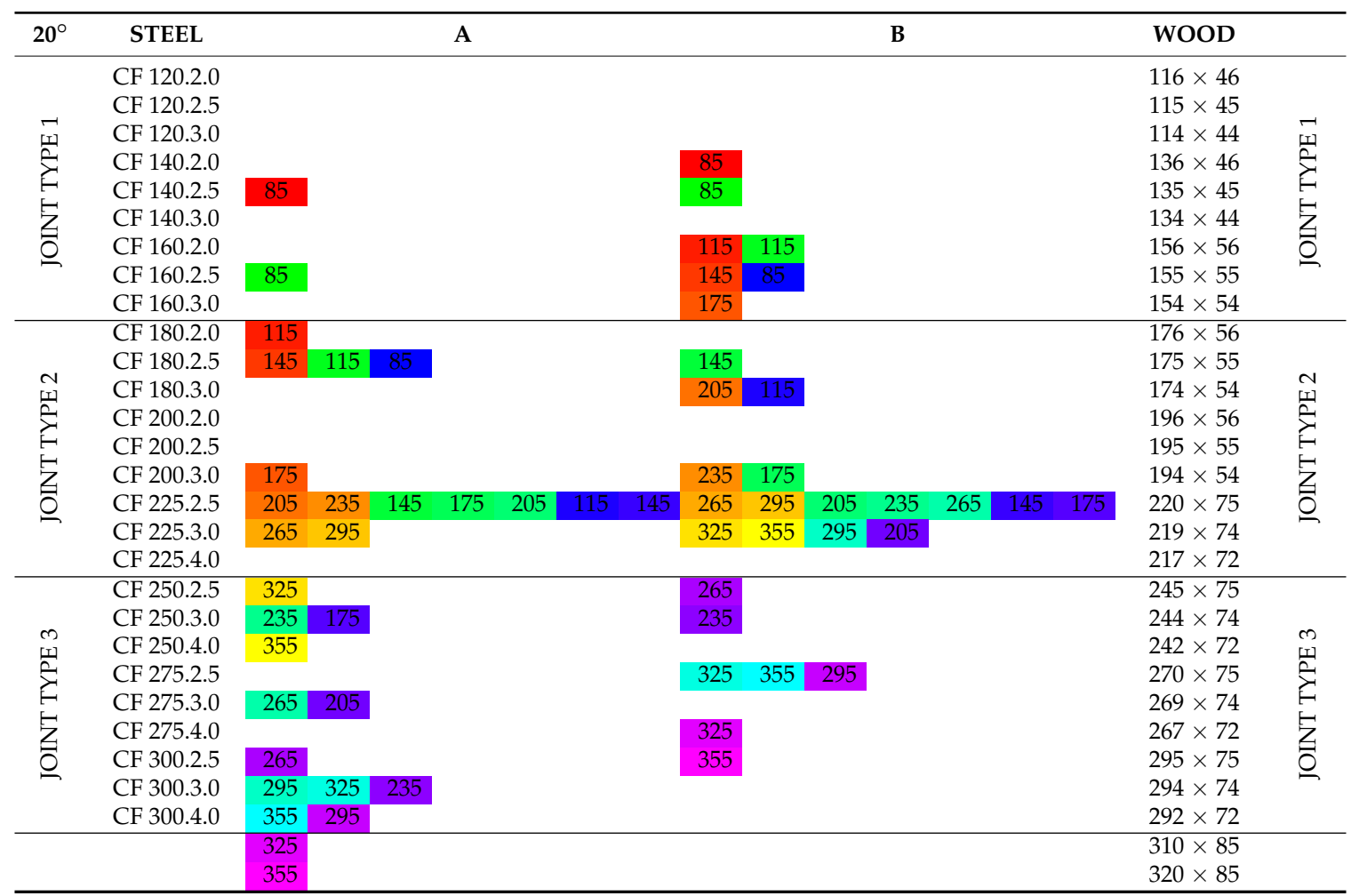




\subsection{Purlin Dimensioning Specifications}

In order to describe the form of operation of the presented design guide, a practical example is presented below. The following case is presented: $7.5 \mathrm{~m}$ span purlins, $20^{\circ}$ of cover inclination and a design load of $175 \mathrm{Kg} / \mathrm{mL}$. Based on these initial data, the purling design process begins in Table 2, from the $175 \mathrm{~kg} / \mathrm{mL}$ column and from the lines corresponding to $7.5 \mathrm{~m}$ of span. In this way we obtain the $P$ parameters for this particular example, which are the following: $\mathrm{P} 1=0.5 \mathrm{~m}, \mathrm{P} 2=0 \mathrm{~m}, \mathrm{P} 3=0.75 \mathrm{~m}$, $\mathrm{P} 4=0 \mathrm{~m}$ and P5 $=0.5 \mathrm{~m}$ (see Figure 3a,b,c). Next, the corresponding 'color + number' for the example are defined in Table 3 which are 'green +175 '. Entering in Table 4 with 'green +175 ', within the column for Section A, the CF 225.2.5 steel profile and the $220 \times 75$ wood section are determined. The same procedure is used in the column for Section B, and the CF 200.3.0 steel profile and $194 \times 54$ wood section are obtained (see Figure $3 a, b, c)$. Table 5 shows the type of union to be applied for this case (they are obtained from the first and last column), being the type 2 in this specific case study (see Figure 10). With all these data and always guided by Figure $3 a, b, c$ and Figure 12, the purlin corresponding to the new presented typology is completely defined.

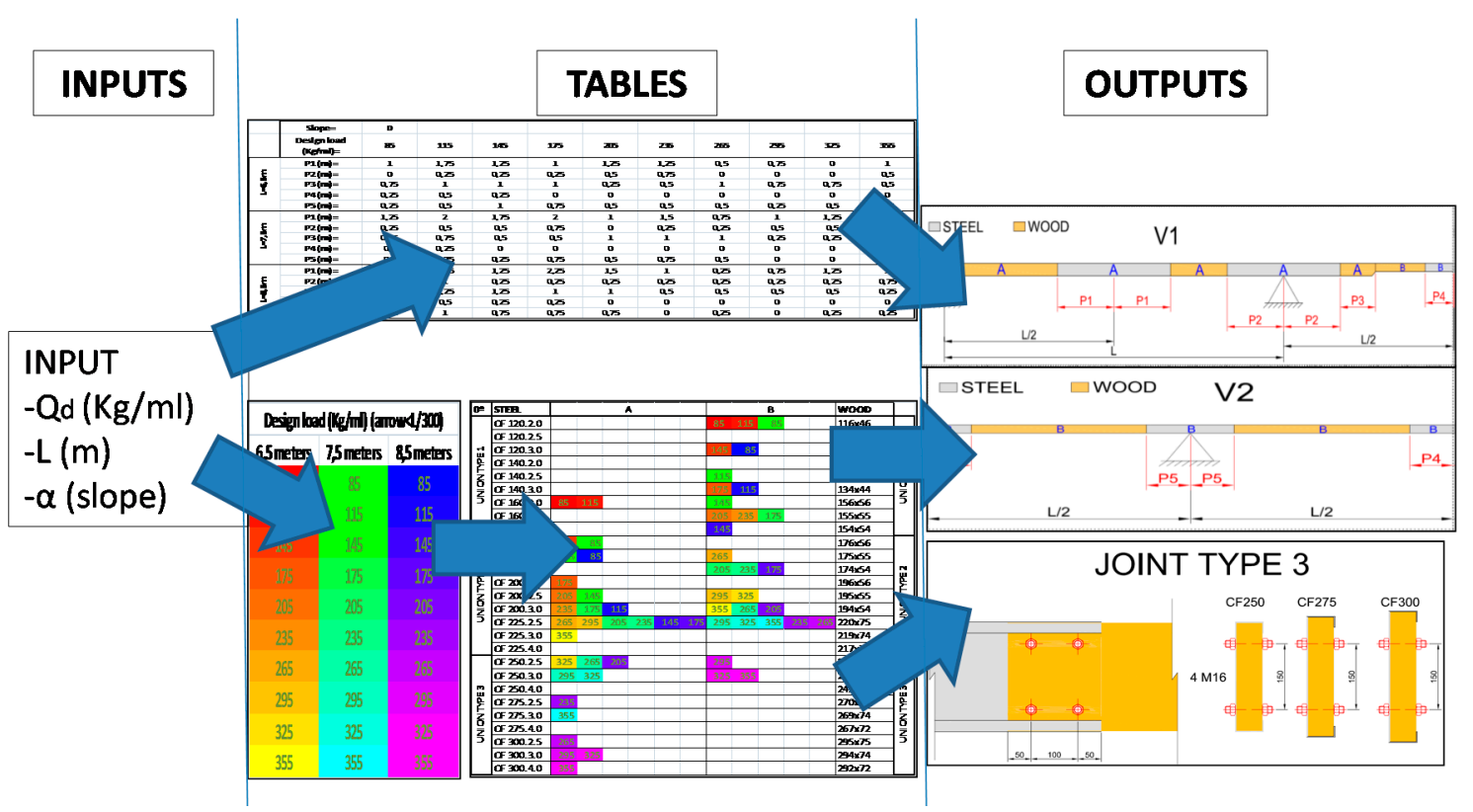

Figure 12. Procedure.

Figure 12 shows a general outline of the procedure to be followed by the structural engineer to calculate and to design the SWP-type purlins.

\section{Conclusions}

This article has presented a new structural typology for roofing purlins, where it has been possible to insert wooden stretches attached to steel stretches without damaging the dimensions of steel but greatly improving the sustainability and overall weight of the roof. It includes a design guide for this new typology of steel + wood purlins using the technical specifications, with which the purlins can be easily and rapidly dimensioned. Therefore, any engineer or architect will be able to dimension this new type of roof structure, thus improving the sustainability level of steel structures, but without harming the geometry, dimensions, or weight of the roof. The main conclusions that have been reached through this research are the following:

- Lighter purlins than the type $\mathrm{C}$ cold rolled steel purlins are obtained with this new structural typology, which also implies reductions in the material needed for the main structure. 
- In the first spans with this type of purlin (continuous over several spans), the predominant design criterion is usually deformation. Given that the elastic modulus of steel is almost 12 times greater than that of wood, in order to obtain good results with regard to this criterion, it is necessary to reinforce the sections of the span centers with sections of cold-formed type $C$ steel.

- When the design criteria is the tensile strength of the material (normally all spans and supports except the first), two situations can occur: in the first, if the design tensile stress values are low and small steel profiles or wooden sections are needed, the result is cold-formed steel sections, because of the small differences between the relative inertia of the two materials and the much higher strength of the steel.

- In the second spans, as the design tensile stress values increase and large wooden or steel profiles are needed, the results become sections of laminated wood, due to the inertias of the rectangular sections that increase much more than those of the type $C$ sections, compensating the shortcomings in terms of material strength.

- A design guide for this new typology of steel + wood purlins has been presented using the technical specifications, with which the purlins can be easily and rapidly dimensioned.

Author Contributions: Conceptualization, H.G. and J.C.; Methodology, H.G., M.Z., and J.C.; Software, J.L.O.; Validation, J.L.O.; Writing-Original Draft Preparation, H.G. and M.Z.

Funding: This research was funded through the Basque Regional Government under the following grant numbers: IT781-13 and IT1314-19.

Conflicts of Interest: The authors declare no conflict of interest. The funders had no role in the design of the study; in the collection, analyses, or interpretation of data; in the writing of the manuscript, or in the decision to publish the results.

\section{References}

1. Gan, V.J.; Chan, C.M.; Tse, K.; Lo, I.M.; Cheng, J.C. A comparative analysis of embodied carbon in high-rise buildings regarding different design parameters. J. Clean. Prod. 2017, 161, 663-675. [CrossRef]

2. Liu, B.; Wang, D.; Xu, Y.; Liu, C.; Luther, M. A multi-regional input-output analysis of energy embodied in international trade of construction goods and services. J. Clean. Prod. 2018, 201, 439-451. [CrossRef]

3. Upton, B.; Miner, R.; Spinney, M.; Heath, L.S. The greenhouse gas and energy impacts of using wood instead of alternatives in residential construction in the United States. Biomass Bioenergy 2008, 32, 1-10. [CrossRef]

4. Cuadrado, J.; Zubizarreta, M.; Pelaz, B.; Marcos, I. Methodology to assess the environmental sustainability of timber structures. Constr. Build. Mater. 2015, 86, 149-158. [CrossRef]

5. Wang, L.; Toppinen, A.; Juslin, H. Use of wood in green building: A study of expert perspectives from the UK. J. Clean. Prod. 2014, 65, 350-361. [CrossRef]

6. Fino, R.; Tadeu, A.; Simões, N. Influence of a period of wet weather on the heat transfer across a wall covered with uncoated medium density expanded cork. Energy Build. 2018, 165, 118-131. [CrossRef]

7. Fino, R.; Simões, N.; Tadeu, A. Numerical and experimental evaluation of the drying behaviour of medium density expanded cork boards used as an external coating. Int. J. Sustain. Dev. Plan. 2017, 12, 315-325. [CrossRef]

8. Tadeu, A.; Moreira, A.; António, J.; Simões, N.; Simões, I. Thermal delay provided by floors containing layers that incorporate expanded cork granule waste. Energy Build. 2014, 68, 611-619. [CrossRef]

9. De la Fuente, A.; Armengou, J.; Pons, O.; Aguado, A. Multi-criteria decision-making model for assessing the sustainability index of wind-turbine support systems: Application to a new precast concrete alternative. J. Civ. Eng. Manag. 2017, 23, 194-203. [CrossRef]

10. Pons, O.; de la Fuente, A.; Armengou, J.; Aguado, A. Towards the sustainability in the design of wind towers. Energy Procedia 2017, 115, 41-49. [CrossRef]

11. Haapio, A.; Viitaniemi, P. A critical review of building environmental assessment tools. Environ. Impact Assess. Rev. 2008, 28, 469-482. [CrossRef]

12. Aguado, A.; Caño Ad de la Cruz MPilar Gomez, D.; Josa, A. Sustainability assessment of concrete structures within the Spanish structural concrete code. J. Constr. Eng. Manag. 2011, 138, 268-276. [CrossRef] 
13. Pons, O.; de la Fuente, A.; Aguado, A. The use of MIVES as a sustainability assessment MCDM method for architecture and civil engineering applications. Sustainability 2016, 8, 460. [CrossRef]

14. de la Fuente, A.; Pons, O.; Josa, A.; Aguado, A. Multi-Criteria Decision Making in the sustainability assessment of sewerage pipe systems. J. Clean. Prod. 2016, 112, 4762-4770. [CrossRef]

15. Caruso, M.C.; Menna, C.; Asprone, D.; Prota, A.; Manfredi, G. Methodology for Life-Cycle Sustainability Assessment of Building Structures. ACI Struct. J. 2017, 114, 323. [CrossRef]

16. Padilla-Rivera, A.; Amor, B.; Blanchet, P. Evaluating the Link between Low Carbon Reductions Strategies and Its Performance in the Context of Climate Change: A Carbon Footprint of a Wood-Frame Residential Building in Quebec, Canada. Sustainability 2018, 10, 2715. [CrossRef]

17. Švajlenka, J.; Kozlovská, M. Perception of User Criteria in the Context of Sustainability of Modern Methods of Construction Based on Wood. Sustainability 2018, 10, 116. [CrossRef]

18. Li, S.; Wu, H.; Ding, Z. Identifying Sustainable Wood Sources for the Construction Industry: A Case Study. Sustainability 2018, 10, 139. [CrossRef]

19. Hafner, A. How building with wood can be linked to sales of building plots: Results from an exemplary site development in Munich, Germany. Sustainability 2017, 9, 947. [CrossRef]

20. Zhang, X.; Shahnewaz, M.; Tannert, T. Seismic reliability analysis of a timber steel hybrid system. Eng. Struct. 2018, 167, 629-638. [CrossRef]

21. Marsono, A.K.B.; Balasbaneh, A.T. Combinations of building construction material for residential building for the global warming mitigation for Malaysia. Constr. Build. Mater. 2015, 85, 100-108. [CrossRef]

22. Balasbaneh, A.T.; Marsono, A.K.B. Strategies for reducing greenhouse gas emissions from residential sector by proposing new building structures in hot and humid climatic conditions. Build. Environ. 2017, 124, 357-368. [CrossRef]

23. Balasbaneh, A.T.; Marsono, A.K.B.; Khaleghi, S.J. Sustainability choice of different hybrid timber structure for low medium cost single-story residential building: Environmental, economic and social assessment. J. Build. Eng. 2018, 20, 235-247. [CrossRef]

24. Stocchero, A.; Seadon, J.K.; Falshaw, R.; Edwards, M. Urban Equilibrium for sustainable cities and the contribution of timber buildings to balance urban carbon emissions: A New Zealand case study. J. Clean. Prod. 2017, 143, 1001-1010. [CrossRef]

25. Woodard, A.; Milner, H. Sustainability of timber and wood in construction. In Sustainability of Construction Materials, 2nd ed.; Elsevier: Amsterdam, The Netherlands, 2016; pp. 129-157.

26. Buchanan, A.; John, S.; Love, S. Life cycle assessment and carbon footprint of multistorey timber buildings compared with steel and concrete buildings. N. Z. J. For. 2013, 57, 9-18.

27. Perez-Garcia, J.; Lippke, B.; Briggs, D.; Wilson, J.B.; Bowyer, J.; Meil, J. The environmental performance of renewable building materials in the context of residential construction. Wood Fiber Sci. 2007, 37, 3-17.

28. Kaziolas, D.; Zygomalas, I.; Stavroulakis, G.; Baniotopoulos, C. LCA of timber and steel buildings with fuzzy variables uncertainty quantification. Eur. J. Environ. Civ. Eng. 2017, 21, 1128-1150. [CrossRef]

29. Jakes, J.E.; Arzola, X.; Bergman, R.; Ciesielski, P.; Hunt, C.G.; Rahbar, N.; Tshabalala, M.; Wiedenhoeft, A.C.; Zelinka, S.L. Not just lumber-Using wood in the sustainable future of materials, chemicals, and fuels. JOM 2016, 68, 2395-2404. [CrossRef]

30. Ward, R. Tackle Climate Change, Use Wood; BC Forestry Climate Change Working Group: Victoria, BC, Canada, 2009.

31. García, H.; Biezma, M.; Cuadrado, J.; Zubizarreta, M. Dual-steel portal frame design to withstand a fire exposure of 45 minutes. Int. J. Steel Struct. 2016, 16, 705-717. [CrossRef]

32. García, H.; Biezma, M.; Cuadrado, J.; Maturana, A. Fire-resistance industrial portal frames: Design with different mechanical properties steels and 35 meters spans. Mater. Struct. 2016, 49, 341-352. [CrossRef]

33. Canto-Perello, J.; Martinez-Garcia, M.P.; Curiel-Esparza, J.; Martin-Utrillas, M. Implementing sustainability criteria for selecting a roof assembly typology in medium span buildings. Sustainability 2015, 7, 6854-6871. [CrossRef]

34. Hein, C.; Lawrence, A.; Snelson, T.; Campbell, A.; Heesbeen, C. Hybrid Timber Construction-Combining Material Properties for Energy Efficiency and Sustainability; IABSE Symposium Report; International Association for Bridge and Structural Engineering: Zurich, Switzerland, 2015.

35. UNE E. 1363: 2000. Fire Resistance Tests; AENOR: Madrid, Spain, 2000. 
36. Hopkin, D. Predicting the thermal response of timber structures in natural fires using computational 'heat of hydration' principles. Fire Mater. 2013, 37, 311-327. [CrossRef]

37. Laranjeira, J.P.d.S.; Cruz, H.; Pinto, A.P.F.; Pina dos Santos, C.; Pereira, J.F. Reaction to fire of existing timber elements protected with fire retardant treatments: Experimental assessment. Int. J. Arch. Herit. 2015, 9, 866-882. [CrossRef]

38. ACCESS-STEEL A. SS053-Proyecto Básico: Diseño de Estructura de Correas; ASCEM: Madrid, Spain, 2012.

39. García, A. End-of-Degree Project: Análisis de Ciclo de Vida Comparativo Entre un Sistema Constructivo de Madera y un Sistema de Hormigón; 2012.

40. MPA the Concrete Centre. Whole-life Carbon and Buildings; MPA the Concrete Centre: London, UK, 2016.

C 2018 by the authors. Licensee MDPI, Basel, Switzerland. This article is an open access article distributed under the terms and conditions of the Creative Commons Attribution (CC BY) license (http://creativecommons.org/licenses/by/4.0/). 